\title{
EFFECT OF USING WEB-BLOG ON WRITING INSTRUCTION FOR ENGLISH LANGUAGE LEARNERS
}

\author{
${ }^{1}$ Taufik Arochman, ${ }^{1}$ Rolisda Yosintha \\ ${ }^{1}$ English Lecturer, Faculty of Education and Teachers Training, Universitas Tidar, Indonesia \\ Corresponding Author Email: taufik_arochman@untidar.ac.id
}

\begin{tabular}{|c|c|}
\hline Article Info & Abstract. \\
\hline Article History & \multirow{8}{*}{$\begin{array}{l}\text { This study was aimed to find out the effectiveness of an intervention using a Web } \\
\text { blog to enhance the academic writing of English Language Learners. It tries to } \\
\text { reveal whether there is any effect in the writing ability of the students taught } \\
\text { using Web blog (online) and that of those taught without using it (offline). This } \\
\text { study was classified as quasi-experimental research. The sample of this research } \\
\text { was } 64 \text { students of X Unggulan Classes (XU1 and XU2) at the secondary school } \\
\text { level in central java. Class XU2 was chosen as the Experimental Group taught } \\
\text { using Web blog media as the treatment employed, whereas Class XU1 as the } \\
\text { Control Group, which was given another treatment (employed paper-based } \\
\text { media). Between the beginning and the end of the study, they were given three } \\
\text { months of treatment. The results showed that there were important effects in the } \\
\text { writing ability of the students taught using Web blog and that of those taught } \\
\text { without using it. It can be seen in the result of the hypothesis testing that the t- } \\
\text { observed (2.028) is higher than the t-table (1.671). }\end{array}$} \\
\hline & \\
\hline & \\
\hline Published: October 2020 & \\
\hline Keywords & \\
\hline & \\
\hline Writin & \\
\hline English Learn & \\
\hline
\end{tabular}

How to cite: Arochman, T \& Yosintha, R (2020). Effect of using web-blog on writing instruction for English language learners. JOLLT Journal of Languages and Language Teaching, 8(4), 336-347, DOI: https://doi.org/10.33394/jollt.v\%vi\%i.2797

\section{INTRODUCTION}

Nowadays, English is widely used for sharing information in many countries in the world (Clyne \& Sharifian, 2008). Mastering English becomes more critical as there are no more constraints between people in the world. The ability of the students in any English language skill will be very beneficial to expand their knowledge related to the subject they are learning. There are some essential skills in learning English. Writing is one of the crucial skills that must be mastered by students (Haerazi \& Irawan, 2019; Indriani, 2019). One of the reasons is that nowadays, more people need to write something in English for specific purposes such as industrial or academic purposes. It can support the students to develop their career after they graduate from their school or college. A well-written resume and application letter with good content and no grammatical errors can add more credibility for them when applying for a job. The skill in writing is crucial for success in college and advance a career (Ranaut, 2018). Hence, students must have excellent capabilities to write well.

Writing is a form of communication by which one can express ideas, opinions, feelings, and so on. Through writing, one can record and depicture the past for the future. It means that it can save one's knowledge on paper over the years and finally make a contribution to others or the writer himself. Besides, it can improve the writer's communication skills. It broadens one's mind and widens imagination. Therefore, the ability to write effectively becomes increasingly essential in the global community.

In Indonesia, writing becomes a requisite skill that should be developed from elementary school up to the university level. Based on the curriculum, it is a sub-skill of English that must be mastered by the students. They should go through writing because it brings some aspects that are useful in the English learning process. Those aspects are 
grammar, punctuation, vocabulary, structure, and cohesive devices. The skill of writing among students in Indonesia is not satisfied yet. This ability is the most challenging skill among the four skills (Abas \& Abd Aziz, 2018). Surveying 150 freshmen representing high schools in Central Java, it concludes that writing is considered the most challenging subject to be learned by the majority of the students. They are barely exposed to the practice of writing. Therefore, students who join in college do not have excellent English writing ability.

The teaching of writing in Indonesia is modelled on the product-oriented approaches. Students have been expected to create a well-written product. The classroom activities used in this approach often involve imitating or copying and changing words from a model text to produce a new paragraph (Jones \& Freeman, 2003). In the product-focused teaching, the English teachers generally pay less attention to other aspects such as the purpose and the processes of composing the text itself. As a result, students are not able to apply the knowledge to produce another varied writing.

As the requirements for effective teaching and learning are not adequately met, the result of teaching writing in schools is not yet satisfactory. The students' writing ability is still low because they face many difficulties in writing. The students who have been taught the material for an extended time (from junior high school to senior high school) cannot even make a simple English sentence yet, and they cannot use English actively (Mart, 2013). Meanwhile, the empirical data from Quin's research shows that the graduated students from the secondary school in Indonesia just master approximately 1000 words. It could hamper the students' choice of words in their writing. These difficulties cause the students to lack their writing performance.

Another problem that makes writing quite demanding for Indonesian students is that English is considered as a foreign language. English is used in specific fields of life or knowledge for certain purposes. It is not used as the daily communication language yet for the Indonesian setting, which mostly does not provide an authentic learning environment. The number of speakers of English in Indonesia is also small. Thus, it is not easy for Indonesian to learn English, which is connected to the "real world." Besides, many researchers state that writing is the most challenging ability for L2 learners. The difficulties lie in developing and constructing ideas, and also in transforming the concepts into an understandable passage.

Some factors can affect the achievement of the process of teaching and learning of writing. Based on the beginning observation at SMA N 1 Cawas, these factors can be categorized into five aspects. They are materials, methods and techniques, media, teachers, and students. All of the aspects contribute to achieving learning. One of these factors is the media. Media are vital components in the teaching-learning process. As we know that the teaching and learning process can not run well without media. They are the resources and equipment available to use in the classroom. Also, the resource can be brought into the classroom. Engaging media can help the students find inspiration for their writing. They will more understand what teachers teach if the teacher provides them with the appropriate media to explain the material. Thus, the aims of teaching could be achieved.

The uses of media are expected to support the teaching and learning of English writing. However, a few educators do not use the media effectively to support the teaching of writing yet. The media used by the teachers in teaching writing were only the original equipment such as boards, chalk, erasers, markers, chairs, and tables. There was no supportive equipment that might promote the students to write. Thus, it is needed an attractive media to support the students learning process. The use of engaging media in learning should fulfil several characteristics, such as accessibility, costs, teaching functions, and interactivity (Manny-Ikan et al., 2011; Sakat et al., 2012).

The media of learning contribute to the process of instructing and learning. It can stimulate learners to build up their idea. Nowadays, the utilization of learning media is often 
related to multimedia, such as a computer and the internet. Some schools have computer laboratories that can be utilized in the learning procedure. However, the use of this media is not maximized yet. The internet connection available in the school is hardly ever used in the writing class. There are some supporting media in learning writing, but the teachers do not use those media since they cannot use them well. Meanwhile, the style in instructing is mainly lecturing, which is not intriguing for the learners. They feel exhausted and not inspired in English, particularly for writing. Thus, the students' motivation in writing English becomes low. Therefore, the learning media are implemented to cope with the problem in SMA N 1 Cawas.

The researcher applied the web blog as an attractive media that are likely to enhance the ability of the students in writing. It is for the reason that web blogs can support the students to investigate and create thoughts as well as substance to write. It can inspire students to develop their ideas in the form of text. Furthermore, the objectives of the study can be defined as follows: To predict whether there is any effect in the writing skill between the students taught using Web-blog (online) and those educated without using it (offline).

As we know, many kinds of technology are used by the people to share media. The capacity of innovation in schools is to improve the process of instructing and learning. Technology is able to enhance the association among the instruction, evaluation strategies, and curriculum. A web blog is a genuinely new instrument for composed correspondence and cooperation and shows up in numerous diverse dialects (Hong, 2008). It becomes a new application today. Web blog gives a space in putting away information. It tends to be utilized as a media in the learning procedure. It is intuitive since it permits learners to convey rapidly and effectively with their cohorts, their instructor, and even with local speakers of the objective language.

Web blog offers several advantages (Hao \& Gao, 2017; Hossain \& Quinn, 2012). It is modest and straightforward to post materials, and ready to peruse in all over the place. It is not difficult to track down in the search machine on the subject, creator, or the two. Web blogs likewise give a device that can be utilized to interface other's web. It makes it easier to join with another side of the world. Besides, web blog links to others have access to people everywhere. Considering the process of instructing and learning of writing skills, including the picking up creative cycle in SMA N I Cawas, which still uses monotonous media to teach writing, can be enhanced by utilizing powerful, appealing, and fitting learning media. A web blog is recognized to be one of those media and is additionally accepted to investigate the intensity of students in writing correctly appropriately.

\section{RESEARCH METHOD \\ Research Design}

This study is categorized as quantitative research. It belongs to a quasi-experimental design. The primary feature of experimental is that researchers manipulate the independent variables. This study involves two variables, the independent variable, and the dependent variable. The principle is that two identical groups are selected: one is as the experimental group that is given special treatment, and the other as the control group that is not given the special treatment. Students of Unggulan 2 implemented web-blog in the learning process. Both groups were given different treatments after the pre-test. Then, the comparison of any differences between the two groups at the end of the experimental period may attribute to the difference in treatment. Treatment is the independent variable that the researcher manipulates to determine its effect on the outcome. In the type of research, both groups were formed randomly. It uses two whole groups that are selected in the groups that have already been created. The dependent variable is the writing ability, which can be seen from the score of the writing test at the end of the learning. 
In this study, some steps were dealing with data collection and processing. In collecting the data, the researcher used a pre-test, treatment, post-test, and scoring. In the pre-test, the researcher wanted to know the writing of the students before they were given any treatments. The tests consisted of two writing essays in which each of the essays should be written down by the students consisting of around 200 words.

Between pre-test and post-test, the students were given treatments. Treatment is the independent variable that the researcher manipulates to determine its effect on the outcome. In this research, the treatment was done twice a week for a month. The special treatment was given to the students of Unggulan Class 2. In every meeting, each class was taught for 90 minutes. The researcher did the treatment for the experimental class by implementing a Web blog in teaching English writing. At the beginning of the lesson, each student had to think about an experience/story that he/she remembered. From planning, the students were given a chance to write their ideas. They typed their experiences using a computer. Then, they made a draft and posted their writing on a Web blog that was designed by the teacher. All the students and the teacher can see their selection. After that, the teacher discussed with the students about the mistakes and errors that they made. The teacher gave them feedback and asked them to revise their writing. Here, they were asked to correct their own mistakes and errors by assistance.

Meanwhile, another treatment was given to the control group. They employed paperbased media. Thus, the students of Unggulan Class 1 were treated as usual by the English teacher using the conventional teaching technique that was the paragraph writing technique. The paragraph writing technique is a prewriting technique in which a person writes continuously for a set period without regard to spelling, grammar, or style (Wibowo, 2019). At the end of the learning, the groups also were given a post-test.

In the post-test, the researcher also measure the writing quality of the students. It was done after they employed the treatments. After both groups were given treatments, the posttest was conducted. The test consisted of two writing essays, which were the same as those used in the pre-test. Both experimental and control groups were given this test. After finishing the post-test, the researcher did the scoring of students' writing test as the first rater and the teacher as the second-rater. Meanwhile, aspects of writing scores are content, organization, discourse, syntax, vocabulary, and mechanics.

\section{Population and Sample}

The population in this study was $10^{\text {th }}$ grade students at Senior High School 1 Cawas, Klaten. It consisted of 310 students. Meanwhile, the sample of the study was two groups of the tenth-grade students of Unggulan 1 and Unggulan 2 of SMA N 1 Cawas. One group was the control group and the other one was the experimental group. In the type of research, both groups were formed randomly. Since it is random, the researcher did not decide the groups by himself. Here, Unggulan 1 was the control class; meanwhile, Unggulan 2 was the experimental class. In the beginning, both groups were given a pre-test. Both groups had the same number of students, which were 32 students each.

\section{Instruments}

The researcher used a writing test to develop examination instruments. These tests were used to find out the scores of students' writing ability. The tools were used both in pre-test and post-test. The instruments were also written based on the syllabus and English lesson in the school. The test covered the materials of writing ability about Curriculum of senior high school Year X in the $1^{\text {st }}$ semester of English Subject.

The researcher used content and constructs validity to measure the validity of the research instruments. In this study, the validity of instruments was achieved by ensuring that the content of the test fairly samples the class or subject matter in question. It could be seen 
that the test was developed about the curriculum of senior high school Year $X$ in the $1^{\text {st }}$ semester of English Subject. Meanwhile, the construct validity was also implemented in this instrument. The writing ability test in this research employed construct validity since it measures the skill of writing.

Moreover, the reliability of instruments in this study was measured by using inter-rater reliability. It was established when the results of the writing test are assessed using subjective judgment. There are two assessors were applied to make the data of the writing score given are reliable. The first assessor was the researcher and the second assessor was a senior high school English teacher.

\section{Data Analysis}

There is two data analysis of this study: descriptive analysis and inferential analysis. In the descriptive analysis, there were mean, standard deviation, and frequency distribution. Meanwhile, in inferential analysis, the researcher did a test of normality, an inspection of homogeneity, and hypothesis testing. First, the Chi-square test was employed to find out that the data was normal. It was gained from the scores of pre-test and post-test. Next, Levene's test was applied to measure the sample variance was similiar. In this study, all the data were in a normal distribution, and the data variance was homogeneous. The last, to reveal the hypothesis which says 'there is a significant difference in the writing ability of the students taught using web blog and those taught using paper-based media,' the t-test was done in both groups. All the data were proceeded by using the SPSS program.

\section{RESEARCH FINDINGS AND DISCUSSION Research Findings}

In this part, the researcher compares the pre-test scores of both classes between the experimental class and control class. From the pre-test results, it can be seen that the mean score of the experimental group is 66.97. On the other hand, the mean score of the control group 67.47. It can be concluded that the mean score of the control group is higher than the mean score of the experimental group. However, it is not quite significant since both classes are classified into an average category. Moreover, both classes are categorized at the same level of writing ability. The result of t-test of pre-test, it shows that $t$-observed $<\mathrm{t}$-table, i.e. $0.303<1.666$ with, also $\mathrm{p}>\alpha$, i.e. $0.763>0.05$. It can be concluded that both classes have no significant difference in the students' writing skill before given web-blog treatment. Therefore, both classes are appropriate to be researched. More explanations are stated as follows.

\section{Descriptive Analysis}

The pre-test data consisted of the pre-test scores and the comparison result of the pretest scores of the students' writing ability of the experimental and that of the control groups. Table 1 gives data about the frequency distribution of the students' writing skills based on the results of the pre-test scores of the experimental class.

Table 1

Frequency Distribution of the Pre-Test Scores of the Experimental Group

\begin{tabular}{llccl} 
No & Interval & Frequency & Percentage & Category \\
\hline 1 & $>82.49$ & 1 & 3.13 & Very good \\
\hline 2 & $67.5-82.49$ & 12 & 37.50 & Good \\
\hline 3 & $52.5-67.49$ & 19 & 59.37 & Average \\
\hline 4 & $37.5-52.49$ & 0 & 0 & Poor \\
\hline 5 & $<37.5$ & 0 & 0 & Very Poor \\
\hline Total & & 32 & $100 \%$ &
\end{tabular}

Table 1 shows that 1 student $(3,13 \%)$ was categorized into a very good category, 12 students $(37.50 \%)$ were categorized into a good category, and 19 students $(59.37 \%)$ were 
categorized into an average category. Moreover, no students were categorized into poor and very poor categories. Therefore, more than half of the students were in an average category of writing ability. For further information regarding the pre-test score of the experimental group can be seen in Table 2.

Table 2

The Descriptive Analysis of the Pre-Test Scores of the Experimental Group

\begin{tabular}{cccccccc} 
Mean & SD & Median & Mode & Highest Score & Lowest Score & Range & Items \\
\hline 66.97 & 6.86 & 66 & 60 & 84 & 56 & 28 & 6
\end{tabular}

Table 2 shows that the mean score of the pre-test of the experimental group was 66.97. Based on the to the table categorization of scores, the students' writing skill of the experimental group was in an average category. It was categorized into the average category because it lies between the scores of $52.6-67.5$.

A pre-test was also implemented to know the students' writing ability in the control group. Table 3 gives data about the frequency distribution of the students' writing ability based on the results of the pre-test scores of the control group.

Table 3:

Frequency Distribution of the Pre-Test Scores of the Control Group

\begin{tabular}{llccl} 
No & Interval & Frequency & Percentage & Category \\
\hline 1 & $>82.49$ & 1 & 3.13 & Very good \\
\hline 2 & $67.5-82.49$ & 14 & 43.75 & Good \\
\hline 3 & $52.5-67.49$ & 17 & 53.12 & Average \\
\hline 4 & $37.5-52.49$ & 0 & 0 & Poor \\
\hline 5 & $<37.5$ & 0 & 0 & Very Poor \\
\hline Total & & 32 & $100 \%$ &
\end{tabular}

Table 3 shows that 1 student $(3.13 \%)$ was categorized into a very good category, 14 students $(43.75 \%)$ were categorized into a good category, and 17 students $(53.12 \%)$ were categorized into an average category. Furthermore, no students were categorized in poor and very poor categories. Therefore, the majority of the students were in an average category of writing ability. For further information regarding the pre-test score of the control group can be seen in Table 4.

Table 4

The Descriptive Analysis of the Pre-Test Scores of the Control Group

\begin{tabular}{cccccccc} 
Mean & SD & Median & Mode & Highest Score & Lowest Score & Range & Items \\
\hline 67.47 & 6.33 & 67 & 64 & 83 & 55 & 28 & 6
\end{tabular}

Table 4 shows that the mean score of the pre-test of the control class was 67.47. Based on the table categorization of scores, it was categorized into an average category because it lies between scores of 52.6 and 67.5. It means that the students' writing ability of the control class was in an average category. Table 5 presents the comparison between the pre-test scores of the students' writing ability of the experimental and that of the control groups.

Table 5

Writing Pre-Test Scores comparison between the Experimental and Control Groups

\begin{tabular}{|c|c|c|c|c|c|}
\hline Group & Data & $\begin{array}{l}\text { Number of } \\
\text { Cases }\end{array}$ & $\begin{array}{l}\text { Sum of } \\
\text { Scores }\end{array}$ & Mean & SD \\
\hline $\begin{array}{l}\text { Experimental } \\
\text { Group }\end{array}$ & $\begin{array}{l}\text { Pre-test } \\
\text { Scores }\end{array}$ & 32 & 2143 & 66.97 & 6.86 \\
\hline $\begin{array}{l}\text { Control } \\
\text { Group }\end{array}$ & $\begin{array}{l}\text { Pre-test } \\
\text { Scores }\end{array}$ & 32 & 2159 & 67.47 & 6.33 \\
\hline
\end{tabular}

Table 5, the mean scores of the pre-test of the experimental and the control groups were categorized into an average category. It is seen as both lie between 52.6 to 67.5. It means that the students' writing ability, both the experimental and control groups were categorized into 
an average category. Then, based on the categorization of the students' writing ability in the pre-test, the majority of the students, both the experimental and control groups, were in an average category.

After conducting the pre-test and treatments, there were continued by giving the posttest. The post-test data consisted of the post-test scores and the comparison result of the posttest scores of the students' writing ability of the experimental and that of the control group. A post-test was implemented to know the students' writing ability after the treatment was applied. Table 6 gives data about the frequency distribution of the students' writing ability based on the results of the post-test scores of the experimental group.

Table 6

Frequency Distribution of the Post-Test Scores of the Experimental Group

\begin{tabular}{llccl} 
No & Interval & Frequency & Percentage & Category \\
\hline 1 & $>82.49$ & 4 & 12.50 & Very good \\
\hline 2 & $67.5-82.49$ & 23 & 71.88 & Good \\
\hline 3 & $52.5-67.49$ & 5 & 15.62 & Average \\
\hline 4 & $37.5-52.49$ & 0 & 0 & Poor \\
\hline 5 & $<37.5$ & 0 & 0 & Very Poor \\
\hline Total & & 32 & $100 \%$ &
\end{tabular}

Table 6 shows that 4 students $(12.50 \%)$ were categorized into a very good category, 23 students $(71.88 \%)$ were categorized into a good category, and 5 students $(15.62 \%)$ were categorized into an average category. Moreover, no students were in poor and very poor categories. Therefore, more than half of the students were in a good category of writing ability. For further information regarding the post-test score of the experimental group can be seen in Table 7.

Table 7

The Descriptive Analysis of the Post-Test Scores of the Experimental Group

\begin{tabular}{lccccccc} 
Mean & SD & Median & Mode & Highest Score & Lowest Score & Range & Items \\
\hline 74.63 & 6.44 & 74 & 74 & 87 & 62 & 25 & 6
\end{tabular}

Table 7 shows that the mean score of the post-test of the experimental class was 74.63. According to the table categorization of scores, it was categorized in a good category. It is because it lies between scores of 67.6 and 82.5. It means that the students' writing ability of the experimental group was improved.

A post-test was also implemented to know the students writing ability in the control group. Table 8 gives data about the frequency distribution of students' writing ability based on the results of the post-test scores of the control group.

Table 8

Frequency Distribution of the Post-Test Scores of the Control Group

\begin{tabular}{lllcl} 
No & Interval & F & Percentage & Category \\
\hline 1 & $>82.49$ & 1 & 3.13 & Very good \\
\hline 2 & $67.5-82.49$ & 21 & 65.62 & Good \\
\hline 3 & $52.5-67.49$ & 10 & 31.25 & Average \\
\hline 4 & $37.5-52.49$ & 0 & 0 & Poor \\
\hline 5 & $<37.5$ & 0 & 0 & Very Poor \\
\hline Total & & 32 & $100 \%$ &
\end{tabular}

Table 8 shows that 1 student $(3.13 \%)$ was categorized into a very good category, 21 students $(65.62 \%)$ were categorized into a good category, and 10 students $(31.25 \%)$ were categorized into an average category. Moreover, no students were in the poor and very poor category. Therefore, more than half of the students were in an average category of writing ability. Meanwhile, the descriptive analysis of the post-test scores of the control group can be seen in Table 9. 
Table 9

The Descriptive Analysis of the Post-Test Scores of the Control Group

\begin{tabular}{lllllllll} 
Mean & SD & Median & Mode & Highest Score & Lowest Score & Range & Items \\
\hline 71.41 & 6.25 & 71 & 70 & 84 & 60 & 24 & 6
\end{tabular}

Table 9 shows that the mean score of the post-test of the control group was 71.41. Based on the table categorization of scores, it was categorized into a good category because it lies between scores of 67.6 to 82.5. It means that the students' writing ability of the control group was in a good category. Table 10 presents the comparison between the post-test scores of the students' writing ability of the experimental and that of the control group.

Table 10

Writing Post-Test Scores comparison between the Experimental and Control Groups

\begin{tabular}{llllll} 
Group & Data & $\begin{array}{l}\text { Number } \\
\text { of Cases }\end{array}$ & $\begin{array}{l}\text { Sum of } \\
\text { Scores }\end{array}$ & Mean & SD \\
\hline $\begin{array}{lllll}\text { Experimental } \\
\text { Group }\end{array}$ & $\begin{array}{l}\text { Post-test } \\
\text { Scores }\end{array}$ & 32 & 2388 & 74.63 & 6.44 \\
\hline $\begin{array}{l}\text { Control } \\
\text { Group }\end{array}$ & $\begin{array}{l}\text { Post-test } \\
\text { Scores }\end{array}$ & 32 & 2285 & 71.41 & 6.25 \\
& & & & &
\end{tabular}

Table 10, the mean scores of the post-test on the writing ability of the experimental and control group, lies between 67.6 and 82.5. It means that the students' writing ability, both of the experimental and control groups, were categorized into a good category. There was an increase of the mean as many as 7.66 points in the experimental group. Besides, an increase of the mean as many as 3.94 points happened in the control group. In other words, the rise of the mean score of the experimental group was higher than that of the control group. Based on the post-test data, the majority of the students of the experimental and the control groups were in a good category.

\section{Inferential Analysis}

There were two points in inferential analysis: pre-analysis and hypothesis testing. To know the normality and homogeneity of the data, the researcher needs to implement a preanalysis in this study. Moreover, to find out whether Web Blog can increase the students' writing ability or not, the t-test formula was applied in hypothesis testing. To know whether the data was standard or not, the researcher tested the data using the chi-square formula. The distribution is considered normal if the value of Chi-square obtained $\left(\mathrm{x}^{2}{ }_{\mathrm{o}}\right)$ is lower than the value of critical formed in the table $\left(\mathrm{x}^{2} \mathrm{t}\right)$ with the significance level of $5 \%$ or if the probability value ( $\mathrm{p}$-value) is higher than 0.05 . The result of the Chi-square analysis of the pre-test is shown in Table 11.

Table 11

\begin{tabular}{lllll}
\multicolumn{4}{c}{ Results of the Normality Test of the Pre-Test } \\
Data & $\mathbf{d f}$ & $\mathbf{x}^{\mathbf{2}} \mathbf{o}^{\mathbf{2}}$ & $\mathbf{x}_{\mathbf{t}}$ & Interpretation \\
\hline Pre-test of the Experimental Group & 13 & 8.25 & 22.362 & Normal \\
\hline Pre-test of the Control Group & 21 & 7.875 & 32.671 & Normal
\end{tabular}

Table 11 shows that the $\mathrm{x}^{2}$ observed score of the pre-test of the experimental and control group was lower than the $x^{2}$ table with the significance level 0.05 . Thus, the distribution was normal. Meanwhile, the result of a Chi-square analysis of the post-test is shown in Table 12.

Table 12

Results of the Normality Test of the Post-test

\begin{tabular}{lcccl} 
Data & $\mathbf{d f}$ & $\mathbf{x}_{\mathbf{0}}$ & $\mathbf{x}_{\mathbf{t}}$ & Interpretation \\
\hline Post-test of the Experimental Group & 13 & 9.125 & 22.362 & Normal \\
\hline Post-test of the Control Group & 14 & 12.062 & 23.685 & Normal
\end{tabular}


Table 12 shows that the $\mathrm{x}^{2}$ observed $\left(\mathrm{x}^{2}{ }_{0}\right)$ score of the post-test of the experimental and control group was lower than the $\mathrm{x}^{2}$ table $\left(\mathrm{x}^{2} \mathrm{t}\right)$ with significance level 0.05 . Therefore, the distribution was normal.

To know whether or not the samples have the homogeneous variance and to show whether or not there is any significant difference in the samples, the researcher did the homogeneity test in this study. Thus, Levene's test was employed. If the value of F-observed $\left(F_{o}\right)$ is lower than F-table $\left(F_{t}\right)$ or if the significant probability level is higher than 0.05 , the sample is classified to be homogeneous. The results of the Levene's test of the pre-test is presented in Table 13.

\begin{tabular}{lllllllll} 
& \multicolumn{8}{c}{ Table 13} \\
Data & $\mathbf{d f}_{\mathbf{1}}$ & $\mathbf{d f}_{\mathbf{2}}$ & $\mathbf{F}_{\mathbf{0}}$ & $\mathbf{F}_{\mathbf{t}}$ & $\mathbf{p}$-value & $\boldsymbol{\alpha}$ & Interpretation \\
\hline Pre-test & 1 & 62 & 0.459 & 3.99 & 0.501 & 0.05 & homogeneous
\end{tabular}

Table 13 shows that the score of $F_{o}$ was lower than $F_{t}$ with the significance level 0.05. Moreover, the $\mathrm{p}$-value of the pre-test was higher than the significance level of 0.05 . Therefore, it can be interpreted that the relationship was homogeneous. Meanwhile, the result of Levene's test of the post-test is shown in Table 14.

Table 14

Result of the Homogeneity Test of the Post-test

\begin{tabular}{llllllll} 
Data & $\mathbf{d f}_{\mathbf{1}}$ & $\mathbf{d f}_{\mathbf{2}}$ & $\mathbf{F}_{\mathbf{0}}$ & $\mathbf{F}_{\mathbf{t}}$ & $\mathbf{p}$-value & $\boldsymbol{\alpha}$ & Interpretation \\
\hline Post-test & 1 & 62 & 0.15 & 3.99 & 0.904 & 0.05 & homogeneous
\end{tabular}

Table 14 shows that the score of $F_{o}$ was lower than $F_{t}$ with significance level 0.05 . In addition, the $\mathrm{p}$-value of the post-test was no lower than the significance level 0.05 . Therefore, it can be interpreted that the relationship was homogeneous.

Next, the researcher conducted hypothesis testing to determine whether the hypothesis was acceptable or not. The hypothesis alternative (Ha) in this study says, "There is a significant difference in writing ability between the grade $X$ senior high school students taught using Web Blog and those taught without using this media." To know the level of difference and significance, the researcher used a t-test formula in this analysis. However, the hypothesis must be changed to the null hypothesis (Ho) before the hypothesis is rejected or accepted. The Ho states that "There is no significant difference in the writing ability between the grade $\mathrm{X}$ senior high school students taught using web Blog and those taught without using it."

After obtaining the pre-test and post-test scores, the researcher measures the mean difference between the post-test mean scores of the experimental group and that of the control group. T-test was implemented after the mean difference was calculated. This test was aiming at to know whether the difference was significant or not. From the post-test, it was found that t-observed $\left(\mathrm{t}_{\mathrm{o}}\right)$ was 2.028 while $\mathrm{t}$-table $\left(\mathrm{t}_{\mathrm{t}}\right)$ was 1.66 . In the meantime, the $\mathrm{t}$-test shows that the p-value was 0.047 , the significance level was $5 \%$, and the degree of freedom was 62 . Statistically, if t-observed is higher than the value of t-table, the Ho is rejected, and the Ha is accepted. In other words, there is a significant difference. However, if t-observed is lower than the value of t-table, the Ho is approved, and the Ha is rejected. In other words, there is no significant difference.

Based on the calculation using SPSS, it was found that t-observed (2.028) was higher than the t-table (1.66). It means that the Ho was rejected, and the Ha was accepted. Thus, there was a significant difference between the results of the post-test of the experimental and the control group. The $t$-test result of the post-test is illustrated in Table 15. 
Table 15

Result of the $t$-test of the Experimental and Control Group in the Post-test

\begin{tabular}{llllll} 
Data & $\mathbf{t}_{\mathbf{0}}$ & $\mathbf{t}_{\mathbf{t}}$ & $\mathbf{d f}$ & $\mathbf{p}$-value & Interpretation \\
\hline Post-test & 2.028 & 1.66 & 62 & 0.047 & Hypothesis accepted
\end{tabular}

With regard to Table 15, it is clear that the $\mathrm{p}$-value was 0.047. Statistically, if the $\mathrm{p}$-value is higher than the significance level, the Ho is accepted, and the Ha is rejected. Thus, there is no significant difference. However, if the $\mathrm{p}$-value is lower than the significance level, Ho is rejected, and the $\mathrm{Ha}$ is accepted. Thus, there is a significant difference. In this research, it is found that the $\mathrm{p}$-value $(0.047)$ was lower than the significance level (0.05). It means that the Ho was rejected, and the Ha was accepted.

After conducting the post-test, there was an increase (7.66) of the score of mean on the experimental class (74.63). Meanwhile, there was an increase (3.94) of the score of mean on the control class (71.41). Based on the increasing data, we can see that improvement of the score of mean on the experimental class is greater than that of the control class. The use of a web blog might influence the improvement of the students writing skills. Also, it can be concluded that the improvement of the experimental class is greater than that of the control class, i.e., $7.66>3.94$. Moreover, $t$-test result of the post-test shows that $t$-observed $>t$-table, i.e. $2.028>1.666$ with, also p-value $<\alpha$, i.e. $0.047<0.05$. Therefore the Ho is rejected properly. In other words, the use of a Web blog shows a significant difference in the ability of students' writing based on the results of the post-test after controlling students' post-test scores.

It can be concluded that the writing ability of the students both in the control and experimental groups in the post-test had a significant difference. In other words, there was a significant difference in the writing ability between the grade $\mathrm{X}$ senior high school students taught using Web blog media and those educated without using this media. Thus, the proposed hypothesis, which states, "There is a significant difference in writing ability between the grade $\mathrm{X}$ senior high school students who are taught using Web blog media and those who are not taught by using it" was accepted.

\section{Discussion}

Based on the study at SMA N 1 Cawas, it is found that there was a significant difference in writing ability between the grade $\mathrm{X}$ senior high school students taught using Web blog media and those taught without using paper-based media. The writing skill of the students taught using the Web blog and those who were not trained using this media before the treatment was the same. It is founded on the result of mean score in the pre-test for both the experimental and control groups.

From the pre-test, it was found that the mean score of the control group (XU1) was 67.47, and the mean score of the experimental group (XU2) was 66.97. The result of the normality test shows that both the experimental and control groups had a normal distribution. Then, founded on the analysis of homogeneity, the result shows that both the experimental and control group was homogenous. The t-observed (0.303) was lower than the t-table (1.66). It means that there was no significant difference between the results of the pre-test of the experimental and control group. The t-test result can also be shown from the $\mathrm{p}$-value. It is found that the $\mathrm{p}$-value $(0.763)$ was higher than the significance level (0.05). The writing ability of the students, both in the control and experimental group in the pre-test, had no significant difference. In other words, as a control and experimental group, they were homogeneous. Thus, the homogeneity of the pre-test is an excellent start to get the valid and reliable results of the experiment.

Meanwhile, the result of the post-test reveals an increase in the score of means for both of the X Unggulan 1 (control class) and X Unggulan 2 (experimental class). However, the 
improvement of the mean score of the experimental group was greater than that of the control group. The improvement of the score of the mean of the experimental group was 7.66, while the control group was 3.94. According to the normality test, both the experimental and control groups had a normal distribution. Based on the homogeneity test, both the experimental and control group was homogenous. Moreover, t-observed (2.028) was higher than the t-table (1.66). Thus, the null hypothesis $(\mathrm{Ho})$ is rejected, and the alternative hypothesis $(\mathrm{Ha})$ is accepted. In other words, there is a significant difference between the results of the post-test of experimental and control groups. The $t$-test result can also be shown from the $p$-value. It is found that the $p$-value $(0.047)$ was lower than the significance level $(0.05)$. The writing ability of the students both in the control and experimental groups in the post-test had a significant difference. It proves that the proposed hypothesis, "There is a significant difference between the students taught using Web blog media and those taught without using this media," was accepted.

Based on the results of the research, the use of web blog media in teaching writing is able to improve the students' writing ability. There are some general reasons for this improvement. The purpose of the Web blog offers several advantages (Fattah, 2016). First, the students could generate their ideas to write freely. It is because the opinions of their writing were about their own life. Then, the routines of producing writing text each meeting could improve the students' language use. They would be accustomed to writing in English with correct grammar, appropriate vocabularies, and the right punctuation. Besides, the teacher could monitor the students' works in every meeting. He might discuss the mistakes and errors that students made. Then, he gave corrections on them and made any suggestions needed. The teacher gave feedback to their writing and asked the students to revise their essays. In the next meeting, the students were asked to make editing based on the feedback given.

As a consequence, it was easy for the students to get a good improvement because they had outstanding media in which they could develop their writing. They also had more opportunities to interact freely with the teacher by the written dialogue, which might occur in the class. It is like Harmer states that the process of writing consists of four stages, namely planning, drafting, editing, and revising (Harmer, 2004).

At last, it can be concluded that the use of Web blog media in the experimental group could enhance the ability of students in writing more than the media used in the control group. Therefore, the use of the web blog media in teaching writing is able to be an additional solution to overcome the students' difficulties in generating ideas and using the appropriate grammar, vocabulary, and punctuation.

\section{CONCLUSION}

Based on the result of the t-test of the Experimental and Control Group in the Post-test, $\mathrm{t}$-observed (2.028) was higher than the t-table (1.66). Besides, according to the $t$-test result, it is found that the $p$-value $(0.047)$ was lower than the significance level (0.05). Therefore, the hypothesis: "There is a significant difference in the writing ability of the students taught using Web Blog and those taught using paper-based media" is accepted. The use of Web blog is able to be alternative media to support the student's practice writings. The researcher suggests that all teachers use the appropriate media in teaching writing. It is also expected that the other researchers are able to develop this study with consideration of the different cultures and linguistic content to improve students' writing skills. 


\section{ACKNOWLEDGEMENT}

The authors realized that the accomplishment of this article would not run well without any help from the others. Therefore, here we want to thank all parties who helped us in completing this article. Then, any criticisms or suggestions from the readers and users are welcome to the researcher in order to make improvement.

\section{REFERENCES}

Abas, I. H., \& Abd Aziz, N. H. (2018). Model of the writing process and strategies of EFL proficient student writers: A case study of Indonesian learners. Pertanika Journal of Social Sciences and Humanities, 26(3), 1-28. http://www.pertanika.upm.edu.my/

Clyne, M., \& Sharifian, F. (2008). English as an International Language: Challenges and Possibilities. Australian Review of Applied Linguistics, 31(3), 28.1-28.16. https://doi.org/10.1111/j.1467-971X.1993.tb00019.x

Fattah, S. F. E. S. A. (2016). The Effectiveness of Using Blogs as an Independent Learning Tool to Develop Reading Skills for University Students. Journal of Education and Practice, 7(32), 65-73.

Haerazi, \& Irawan, L. A. (2019). Practicing Genre-Based Language Teaching Model to Improve Students' Achievement of Writing Skills. Indonesian Journal of English Language Teaching and Applied Linguistics, 4(1), 9-18. https://doi.org/http://dx.doi.org/10.21093/ijeltal.v4i1.246

Hao, J., \& Gao, B. (2017). Advantages and Disadvantages for Nurses of Using Social Media. Journal of Primary Health Care and General Practice, 1(1), 1-3.

Harmer, J. (2004). How to teach writing. Pearson Education Ltd.

Hong, W. (2008). Exploring Educational Use of Blogs in U.S. Education. US-China Education Review, 5(10), 34-38.

Hossain, M., \& Quinn, R. J. (2012). Advantages and Disadvantages of Using a Blogging Activity in a College Euclidean Geometry Course. International Journal of Computer Technology and Electronics Engineering, 2(6), 25-26.

Indriani, L. (2019). Developing Pre-Service English Teachers' Critical Thinking By Using Academic Journal Writing 4.0. Metathesis: Journal of English Language, Literature, and Teaching, 3(2), 117-123. https://doi.org/10.31002/metathesis.v3i2.1859

Jones, A. A., \& Freeman, T. E. (2003). Imitation, Copying, and the Use of Models: Report Writing in an Introductory Physics Course. IEEE Transactions on Professional Communication, 46(3), 168-184. https://doi.org/10.1109/TPC.2003.816790

Manny-Ikan, E., Dagan, O., Berger Tikochinski, T., \& Zorman, R. (2011). Using the Interactive White Board in Teaching and Learning - An Evaluation of the SMART CLASSROOM Pilot Project. Interdisciplinary Journal of E-Learning and Learning Objects, 7, 249-273. https://doi.org/10.28945/1523

Mart, Ç. T. (2013). Teaching grammar in context: Why and how? Theory and Practice in Language Studies, 3(1), 124-129. https://doi.org/10.4304/tpls.3.1.124-129

Ranaut, B. (2018). Importance of Good Business Writing Skills. International Journal of Language and Linguistics, 5(2), 32-41. https://doi.org/10.30845/ijll.v5n2a5

Sakat, A. A., Zin, M. Z. M., Muhamad, R., \& Ahmad, A. (2012). Educational Technology Media Method in Teaching and Learning Progress. American Journal of Applied Sciences, 9(6), 874-878. https://doi.org/10.3844/ajassp.2012.874.878

Wibowo, F. E. (2019). The Effectiveness of Guided Reciprocal Peer Questioning (GRPQ) in Teaching Writing Viewed from Creativity. Metathesis: Journal of English Language, Literature, and Teaching, 3(1), 12-25. https://doi.org/10.31002/metathesis.v3i1.1190 